\title{
Bowhunter's syndrome
}

\author{
Ramesh Grandhi, ${ }^{1}$ Neal Godse, ${ }^{2}$ Richard W Williamson, ${ }^{2}$ Ricardo A Hanel ${ }^{1}$
}

${ }^{1}$ Lyerly Neurosurgery, Baptist Neurological Institute, Jacksonville, Florida, USA ${ }^{2}$ University of Pittsburgh School of Medicine, Pittsburgh, Pennsylvania, USA

\section{Correspondence to}

Dr Ricardo Hanel, rhanel@|yerlyneuro.com

Accepted 26 May 2015

\section{CrossMark}

To cite: Grandhi $R$, Godse N, Williamson RW, et al. BMJ Case Rep Published online: [please include Day Month Year] doi:10.1136/bcr-2015210654

\section{DESCRIPTION}

A 47-year-old man with a previous remote posttraumatic rotational neck injury with operative repair of a neck laceration and a recent right occipital stroke, presented with syncope when turning his head to the right. Diagnostic cerebral angiography demonstrated an atretic left vertebral artery ending extracranially; in a neutral position, the dominant right vertebral artery exhibited mild stenosis from an osteophyte at C5-6. On rotating the patient's head to the right, the right vertebral artery became occluded (figure 1).

The patient underwent a right-sided anterior neck approach for vertebral artery decompression at C5-6 (figure 2). Following discharge, he no longer experienced syncopal events when turning his head to the right.

Bowhunter's syndrome is a neurovascular condition characterised by dynamic rotational occlusion of the dominant vertebral artery. ${ }^{1}$ First described by Sorenson in 1978, Bowhunter's syndrome is so named because the symptoms are commonly elicited by rotating the head into a position similar to that which an archer adopts while using a bow and arrow. $^{2}$ Symptoms range from presyncopal lightheadedness to lateral medullary (Wallenberg) stroke. $^{3}$

Aberrant bony and fibroligamentous anatomy along the course of the vertebral arteries accounts for the majority of cases. A consistent theme, though, is that rotation of the head causes compression of the dominant vertebral artery, which, when coupled with diminished or absent flow through the contralateral, non-dominant vertebral artery, leads to posterior circulation ischaemia. The gold standard for diagnosis of Bowhunter's

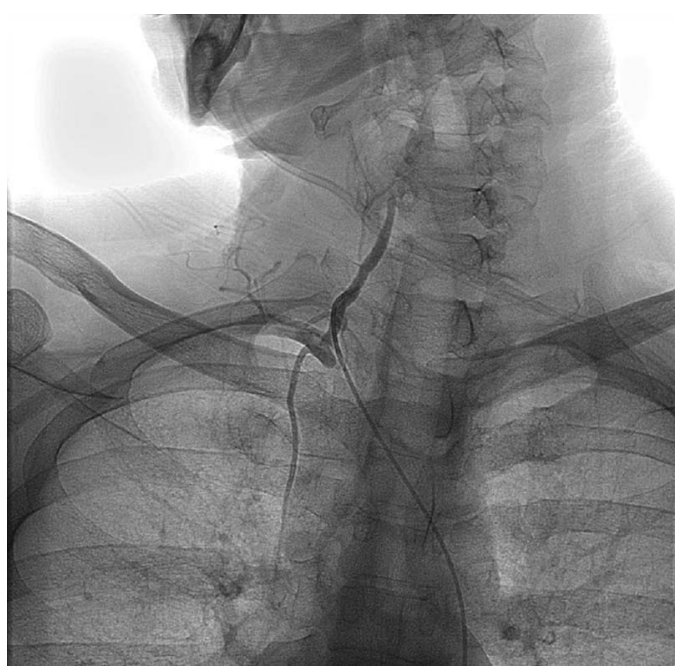

Figure 1 Diagnostic cerebral arteriogram, anteroposterior view, demonstrates right vertebral artery V2 segment occlusion with patient's head rotated to the right.

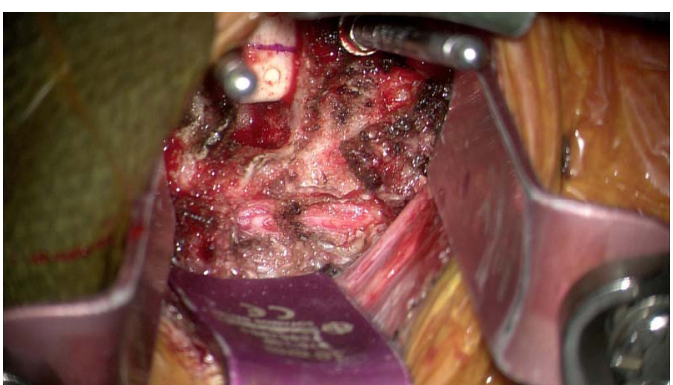

Figure 2 Intraoperative picture following right vertebral artery decompression within the foramina transversia at C5-6.

syndrome is digital subtraction angiography to demonstrate the occlusion when the patient is in the causative position. ${ }^{3}$ Definitive management of Bowhunter's syndrome is surgical decompression at the site of the occlusion. Endovascular management of non-dominant vertebral artery stenosis has been proposed as well. ${ }^{3}$

\section{Learning points}

- The symptoms of Bowhunter's syndrome include presyncopal lightheadedness to lateral medullary (Wallenberg) stroke.

- The symptoms become apparent on turning the head.

- The diagnosis involves diagnostic cerebral angiography both in a neutral position and with the head turned.

Contributors RG and RH contributed in the study concept and design. NG was involved in the acquisition of data. All the authors contributed in the analysis and interpretation of data. RG and NG participated in the drafting of the manuscript. RG and $\mathrm{RH}$ performed critical revision of the manuscript for important intellectual content. RG and RWW provided administrative, technical and material support. RH is the study supervisor.

Competing interests None declared.

Patient consent Obtained.

Provenance and peer review Not commissioned; externally peer reviewed.

\section{REFERENCES}

1 Matsuyama T, Morimoto T, Sakaki T. Bow hunter's stroke caused by a nondominant vertebral artery occlusion: case report. Neurosurgery 1997:41:1393-5.

2 Sorensen BF. Bow hunter's stroke. Neurosurgery 1978;2:259-61.

3 Taylor WB, Vandergriff CL, Opatowsky MJ, et al. Bowhunter's syndrome diagnosed with provocative digital subtraction cerebral angiography. Proc (Bayl Univ Med Cent) 2012;25:26-7. 


\section{Images in...}

Copyright 2015 BMJ Publishing Group. All rights reserved. For permission to reuse any of this content visit http://group.bmj.com/group/rights-licensing/permissions.

BMJ Case Report Fellows may re-use this article for personal use and teaching without any further permission.

Become a Fellow of BMJ Case Reports today and you can:

- Submit as many cases as you like

- Enjoy fast sympathetic peer review and rapid publication of accepted articles

- Access all the published articles

- Re-use any of the published material for personal use and teaching without further permission

For information on Institutional Fellowships contact consortiasales@bmjgroup.com

Visit casereports.bmj.com for more articles like this and to become a Fellow 